\title{
Imprecise data envelopment analysis model for robust design with multiple fuzzy quality responses
}

\author{
Al-Refaie, A. ${ }^{a}{ }^{*}$, Li, M.-H. ${ }^{b}$, Jarbo, M. ${ }^{a}$, Yeh, C.-H.B. ${ }^{b}$, Nour, B. ${ }^{a}$ \\ ${ }^{a}$ Department of Industrial Engineering, The University of Jordan, Amman, Jordan \\ ${ }^{b}$ Department of Industrial Engineering and Systems Management, Feng Chia University, Taichung, Taiwan
}

\begin{abstract}
A B S T R A C T
In this research, Imprecise Data Envelopment Analysis (IDEA) model was utilized to improve fuzzy multiple responses in robust design. The combination of process factor levels at each experiment was considered as a Decision Making Unit (DMU) with responses treated as inputs and outputs for all DMUs. The Fuzzy C-Means Clustering (FCMC) technique is used to fit the response fuzziness by clustering the average values, relative to each response, into a suitable number of clusters with triangular / trapezoidal membership functions. IDEA models were used to estimate the fuzzy triangular/trapezoidal efficiency values for each DMU. Finally, the preference degree-based ranking approach was used to discriminate between the fuzzy efficiency values and identifying the best combination of factors levels that would improve fuzzy multiple responses. Two case studies are utilized to illustrate the proposed approach, including optimizing wire electrical discharge machining and sputtering process parameters. The results showed that the proposed approach provides better anticipated improvements than the fuzzy multiple regression based approach. This approach would provide great assistant to process engineers in improving process performance with fuzzy multiple responses over a wide range of business applications.
\end{abstract}

\section{ARTICLE INFO}

Keywords:

Imprecise data envelopment analysis

Robust design

Multi fuzzy quality response

*Corresponding author: abbas.alrefai@ju.edu.jo (Al-Refaie, A.)

Article history:

Received 30 September 2013

Revised 23 April 2014

Accepted 5 May 2014 


\title{
Model analize ovojnice nenatančnih podatkov $z$ večkratnimi mehkimi odzivi za robustno načrtovanje
}

\author{
Al-Refaie, A. ${ }^{a}{ }^{*}$, Li, M.-H. ${ }^{b}$, Jarbo, M. ${ }^{a}$, Yeh, C.-H.B. ${ }^{b}$, Nour, B. ${ }^{a}$ \\ ${ }^{a}$ Department of Industrial Engineering, The University of Jordan, Amman, Jordan \\ ${ }^{b}$ Department of Industrial Engineering and Systems Management, Feng Chia University, Taichung, Taiwan
}

\section{POVZETEK}

$\mathrm{V}$ raziskavi je bil uporabljen model analize ovojnice nenatančnih podatkov (angl. Imprecise Data Envelopment Analysis - IDEA) za izboljšanje večkratnih mehkih odzivov za robustno načrtovanje. Kombinacija ravni procesnih faktorjev se je pri vsakem eksperimentu upoštevala kot enota odločanja (angl. Decision Making Unit - DMU) z odzivi, obravnavnimi kot vhodi in izhodi za vse enote DMU. Tehnika mehkih C-povprečij (angl. Fuzzy C-Means Clustering FCMC) je bila uporabljena za prilagoditev mehkega odziva s kopičenjem povprečnih vrednosti (relativno k vsakem odzivu) v ustrezno število gruč s trikotno / trapezoidno funkcijo pripadnosti. Modeli IDEA so bili uporabljeni za oceno mehkih vrednosti učinkovitosti za vsak DMU. Na koncu je bilo uporabljeno prednostno stopenjsko razvrščanje za razločevanje med mehkimi vrednostmi učinkovitosti in ugotavljanje najboljše kombinacije ravni faktorjev za izboljšanje večkratnih mehkih odzivov. Za prikaz delovanja predlaganega pristopa smo uporabili dve študiji primerov, ki prikazujeta optimizacijo žične elektroerozijske obdelave in optimizacijo procesnih parametrov pri postopku nanašanja materiala. Rezultati kažejo, da predlagan pristop omogoča boljše rezultate kot mehki pristop, ki temelji na multipli regresijski metodi. Poleg tega zagotavlja izdatno pomoč procesnim inženirjem pri izboljšanju zmogljivosti procesa z večkratnimi mehkimi odzivi za široko paleto poslovnih aplikacij.

\section{PODATKI O ČLANKU}

Ključne besede:

Analize ovojnice nenatančnih podatkov

Robustno načrtovanje

Večkratni mehki odzivi

*Kontaktna oseba:

abbas.alrefai@ju.edu.jo

(Al-Refaie, A.)

Zgodovina članka:

Prejet 30. septembra 2013

Popravljen 23. aprila 2014

Sprejet 5. maja 2014 


\section{References}

[1] Liao, H.-C., Chen, Y.-K. (2002). Optimizing multi-response problem in the Taguchi method by DEA based ranking approach, International Journal of Quality \& Reliability Management, Vol. 19, No.7, 825-837, doi: 10.1108/02 656710210434766.

[2] Reddy, P.B.S, Nishina, K., Babu A.S. (1997). Unification of robust design and goal programming for multiresponse optimization - a case study, Quality and Reliability Engineering International, Vol. 13, No. 6, 371-383.

[3] Hsu, C.-M. (2001). Solving multi-response problems through neural networks and principal component analysis, Journal of the Chinese Institute of Industrial Engineers, Vol. 18, No. 5, 47-54, doi: 10.1080/10170660109509504.

[4] Salmasnia, A., Kazemzadeh, R.B., Niaki, S.T.A. (2012). An approach to optimize correlated multiple responses using principal component analysis and desirability function, The International Journal of Advanced Manufacturing Technology, Vol. 62, No. 5-8, 835-846, doi: 10.1007/s00170-011-3824-2.

[5] Al-Refaie, A. (2012). Optimizing performance with multiple responses using cross-evaluation and aggressive formulation in data envelopment analysis, IIE Transactions, Vol. 44, No. 4, 262-276, doi: 10.1080/0740817X. 2011.566908.

[6] Al-Refaie, A., Wu, T.-H, and Li, M.-H. (2009). Data envelopment analysis approaches for solving the multiresponse problem in the Taguchi method, Artificial Intelligence for Engineering Design, Analysis and Manufacturing, Vol. 23, No. 2, 159-173, doi: 10.1017/S0890060409000043.

[7] Al-Refaie, A. (2010). Grey-data envelopment analysis approach for solving the multi-response problem in the Taguchi method, In: Proceedings of the Institution of Mechanical Engineers, Part B: Journal of Engineering Manufacture, Vol. 224, No. 1, 147-158, doi: 10.1243/09544054JEM1525.

[8] Al-Refaie, A., Rawabdeh, I., Abu-alhaj, R., Jalham, I.S. (2012). A fuzzy multiple regressions approach for optimizing multiple responses in the Taguchi method, International Journal of Fuzzy System Applications, Vol. 2, No. 3, 13-34, doi: 10.4018/ijfsa.2012070102.

[9] Hsieh, K.-L., Tong, L.-I. (2001). Optimization of multiple quality responses involving qualitative and quantitative characteristics in IC manufacturing using neural network, Computers in Industry, Vol. 46, No. 1, 1-12, doi: 10.1016/S0166-3615(01)00091-4.

[10] Al-Refaie, A., Li, M.-H. (2011). Optimizing the performance of plastic injection molding using weighted additive model in goal programming, International Journal of Fuzzy System Applications, Vol. 1, No. 2, 43-54, doi: $10.4018 /$ ijfsa.2011040104.

[11] Kim, K., Lin, D. (2000). Simultaneous optimization of multiple responses by maximizing exponential desirability functions, Journal of the Royal Statistical Society: Series C (Applied Statistics), Vol. 49, No. 3, 311-325.

[12] Kim, K.-J., Lin, D.K.J. (2006). Optimization of multiple responses considering both location and dispersion effects, European Journal of Operational Research, Vol. 169, No. 1, 133-145, doi: 10.1016/i.ejor.2004.06.020.

[13] Fung, C.-P., Kang, P.-C. (2005). Multi-response optimization in friction properties of PBT composites using Taguchi method and principle component analysis, Journal of Materials Processing Technology, Vol. 170, No. 3, 602-610, doi: 10.1016/i.jmatprotec.2005.06.040.

[14] Khalili-Damghani, K., Taghavifard, M., Olfat, L., Feizi, K. (2011). A hybrid approach based on fuzzy DEA and simulation to measure the efficiency of agility in supply chain: real case of dairy industry, International Journal of Management Science and Engineering Management, Vol. 6, No. 3, 163-172.

[15] Zhu, J. (2003). Imprecise data envelopment analysis (IDEA): A review and improvement with an application, European Journal of Operational Research, Vol. 144, No. 3, 513-529, doi: 10.1016/S0377-2217(01)00392-7.

[16] Shokouhi, A.H., Shahriari, H., Agrell, P.J., Hatami-Marbini, A. (2014). Consistent and robust ranking in imprecise data envelopment analysis under perturbations of random subsets of data, OR Spectrum, Vol. 36, No. 1, 133-160, doi: $10.1007 / \mathrm{s} 00291-013-0336-5$.

[17] Jahanshahloo, G.R., Abbasian-Naghneh, S. (2011). Data envelopment analysis with imprecise data, Applied Mathematical Sciences, Vol. 5, No. 62, 3089-3106.

[18] Wang, Y.-M., Luo, Y., Liang, L. (2009). Fuzzy data envelopment analysis based upon fuzzy arithmetic with an application to performance assessment of manufacturing enterprises, Expert Systems with Applications, Vol. 36, No. 3(Part 1), 5205-5211, doi: 10.1016/i.eswa.2008.06.102. 